\title{
THE ANTHRACNOSES OF CITRUS FRUITS, MANGO AND AVOCADO
}

\author{
J. A. B. NoLtA \\ INTRODUCTION
}

The present paper presents a comparative study of the anthracnose diseases of the mango, avocado, and citrus fruits to determine the causal relations of Colletotrichum gloeosporioides Penz., Gloeosporium limetticolum. Clausen and possibly other species of fungi to these diseases.

The diseases known as blossom blight, leaf spot, and fruit rot oi the mango (Mangifera indica $\mathrm{L}$.) have been reported to be caused by the fungus Colletotriclium gloeosporioides Penz. by Bessey (1), Cardin (3), Fawcett (15), Mc Mruran (25) and others (7, 27, 38). Higgins (19) leports mango blight in Hawaii caused by a species of Colletotrichum. However, Nowell (26) says that the fungus is usually known as Glocosporium mangiforce Henn., but that it has also been known as Collototrichum glocosporioides Penz. Again Cook (10) and Fawcett (1. c.) hold that blossom blight is caused by Gloeosporium mangiferce and Stevens (35) reports the same fungus on mango leaves.

A similar disease is found on the avocado (Persea Persea L). A species of Colletotrichum has been found to cause black spot and has been isolated from the tissues of diseased fruits, stems and twigs. The identity of this fungus with Colletotrichum glocosporigides has been maintained by different writers $(10,26,27$ and 37$)$.

The wither-tip, blossom blight, and fruit canker of the limes has been studied thoroughly along with the wither-tip, spotting of leaves and fruit, and streaking of the fruit of other citrus trees, $i$. e., pomelo and orange. Hume (20) and Massee (24) give information concerning the anthracnose of the pomelo; Cook (8) reports Colletotrichum glocosporioides as causing the anthracnose of citrus fruits including the lime. Duggar (11) and Rolfs (29) sustain the same view as Cook as to the host relations of the pathogenes. Clausen (5) finds that Colletotrichum glocosporioides is not responsible for the wither'tip of the lime. He studied and described another organism, Gloeosporium limetticolum. It appears from his and later investigations by Fulton (7) that the true pathogene of the lime is Glocosporium limetticolum, while Colletotrichum glocosporioides is 
restricted to other hosts, especially eitrus fruits other than lime, and further that it is not an active pathogene. Faweet (16) separates the two pathogenes in like manner. Cook (1. c.) in 1906 advanced the statement that "the fungus which has been grown in pure cultures proceeding from these large spots on the leaves is not the same as that which we obtained from the withered leaves of the lime." Nowell (1. e.) believes that $C$. gloeosporioides is a weaker parasite than $G$. limetticolum. Furthermore, he dwells upon the fact that the former partakes mainly of the nature of a saprophyte. The same position has been taken by Thomas (42).

In the opinion of the writer, Colletotrichum gloeosporioides Penz is the cause of the anthraenose of the mango, orange, pomelo, lemon, avocado and may be the cause of the wither-tip of limes. ${ }^{1}$ Again we have found Colletotrichum gloeosporioides causing the lime withertip only in a few cases, while Gloeosporium limetticolum occurs more frequently especially in fruit spots. In this way we have verified Clau'sen's (1. c.) and Fulton's (1. c.) findings and conclusions that Gloeosporium limetticolum is an active pathogene of the lime. However, we differ from their views and also the views of Winston (44) as to the pathogenicity of Colletotrichum glocosporioides. Quoting Fulton: "Winston, in connection with his studies of citrus tear stain, was unable to find, among numerous strain's of C. gloeosporioides tested, any indication of active pathogenicity on very young fruits of various citrus species." We found during the past year a heavy shedding of the young fruit of lemon, orange, and pomelo. The cartse for a considerable part of this shedding was found to be C. gloeosporioides. All strains from the hosts used in this investigation were obtained from such fallen small fruits. Thus, our position, in this question will be that $C$.gloeosporioides is, at least under Porto Rican conditions, an active pathogene.

A brief history and diseussion of the diseases are given in this paper and cross-inoculation experiments and cultural characteristics are presented in detail.

\section{PART I}

\section{HISTORY AND DESCRIPTION OF THESE DISEASES}

Anthracnose of Citrus Trees other than Limes. (Colletotrichum gloeosporioides Penz.)

The causal fungus was first studied and described by Penzig in 1882. In 1904, Rolfs (29) described the disease from Florida. In

I'llis opinion is based on the studies of Porto Rienn material with reference to the pulblished liferature and not on the examination of the type material. 
1909, it was reported from Porto Rico by Fawcett (14) and in the same year, by Essig (13) from Santa Paula, California. Other reports record the disease in Cuba, Australia, Italy, Malta, Jamaica, Mexico and Brazil.

The disease occurs as a fruit and leaf spot, fruit drop and as a wither-tip of twigs. The symptoms are like those of the lime anthracnose except for the fruit and leaf spot. Spots of leaves occur only on debilitated or weak parts of the tree and only on old leaves. Fruit spots are to be found when the fruit has been bruised or injured. The fungus will enter through wounds and in moist weather particularly will produce a rot which progresses rapidly into the core resulting in a blackening of the tissues and seeds. The spots grow to be $5-6 \mathrm{~cm}$. in cliameter. The color of the spots is at first fleshy but later changes to a mummy brown or a chestnut brown.

This fungus in Porto Rico was found to be the cause of a heavy drop of the young firuits of the orange, pomelo and Chinese dwarf lemon, when $1 / 4$ to 1 or $1 \frac{1 / 4}{4}$ inches in diameter. The drop occurred during the month of May and was especially destructive in the vicinity of the Station and in the Bayamón district. The conditions prevailing at the time were warm weather with heavy rains. The young fruit when gathered from the ground showed a distinct browning at the stem end. When cut longitudinally the inside was found to vary from a fleshy to brown color and this coloration marks the progress of the fungus outward to the blossom end. The fungus has been isolated from bits of the tissues of the inside of orange, lemon, and pomelo fruits exhibiting these symptoms. The fungus was also found on grapefruit flowers which had dropped to the ground and con the spurs from which the fruits had fallen.

\section{Anthracnose of Limes.}

Nowell (26) reports that an epidemic of the fungus Gloeosporinm limetticolum occurred in Trinidad in the months of July and August, 1918. From that time the disease spread, resulting in a failure of the lime industry there. The disease also occurs in British Guiana and in 1919 Nowell found the fungus on material sent from there. He also gives account of the appearance of the disease in Dominica in 1922. Other reports show it to be present also in Cuba, Jamaica, Australia, Italy, Brazil, Malta and Mexico but it has not been found in California.

The fungus attacks tender foliage, blossoms and fruits. On young shoots the disease commenees on the unopened whorl of leaves which 
soon die, and from there progresses dorwn for 3.5 or more centimeters. In our inoculations on small seedlings we have observed a similar effeet. Fruiting bodies of the fungus appear rapidly on the surface of dead twigs under favorable moisture conditions, thus furnishing a constant source of inoenlum.

On the inflorescence the disease may be described as follows: On unopened buds small brown discolorations appear. These grow in all directions and ordinarily cause the falling of the buds before they open. On expanded flowers the characteristic discolorations occur on petals, stigmas and styles but are most common on the stigmas (see fig. 2). There is much shedding of young fruit and in badly infested trees it is very seldom that we find healthy fruit.

Fruits that survive the period of greatest danger of infection ray be attacked later. Cook and Horne (9) stated that infection of sour lime did not take place after the fruits were well set and Clausen (5) supports the same view. We have covered flower clusters with paper bags before the opening of the flower buds and when the fruits were about one-half or three-fourths of: an inch in diameter the bags were removed. The fruit which appeared healthy was thus exposed to inoculation. Later observations showed that nove than 50 per cent of such fruits took the disease, the cankers being produced as under normal conditions except that they were smaller. In that case circular to oblong spots which vary in size from 1-3.5 cm. $\times 2 \mathrm{~cm}$. appear on the surface. At first the spots are brownish but with inereasing size and age they turn to a fleshy color and the skin of the fruit is ruptured or cracked in many places, producing the elaracteristic cankers. In some cases the eracking is so pronounced and rapid that it includes a part of the adjacent healthy tissues. This cracking may occur in two directions but ordinarily, in one. It is not uncommon to see the fruit split along its whole length or width. The writer has seen some cases in which the rupturing of the skin or rind has progressed in both directions along the same path; $i$. e., a longitudinal rupture has tumed to the side and worked its way transversely, or vice versa, making a circular split around the fruit. The vesicles of the fruit are exposed on rupturing of the rind and carpel membrane, and there always seems to occur an abnormal enlargement of the same. There is also a gumming exudation.

\section{Mango Anthracnose.}

The first report of a mango blight appears to have been made 
by Cobb. (6a) in 1894. The symptoms of the disease are spotting of the leaves and fruit and a blighting of the blossoms. The spots on the leaves range from $5-10 \times 7-25 \mathrm{~mm}$. Some of them extend from the margin, between the main veins, toward the midrib. In some instances two or three spots coalesce, forming irregular areas. It appears that the fungus starts growing on both sides and midway between the midrib and the margin of the blades. The spots increase in size and extend to the margin. The center of the spot is ochraceous-orange ${ }^{1}$ at first, becoming cinnamon-rufous with age. This particular spotting has been found in only one instance. On the fruit the disease appears as very small brown spots. These spots enlarge very soon; especially under moist conditions. With the increase in size of the spots there is an intensification of their color to almost black and splitting or cracking of the rind and a sinking of the affected area included in the spots. The spots, very often coalesce, forming large irregular areas which sometimes cover the entire rind of the fruit. The spots are commonly found at or around the stem end region. Streaking is seldom observed in Porto Rico. The damage done to the fruit is very great and this seems to be true in other places.

The blossom blight is particularly destructive in this Island. the fungus attacks open flowers and young flower buds and may result in the destruction of the panicles. Various writers have established a definite relation between weather conditions and the damages done by the disease on the blossoms. Collins (7) from Porto Rico and Higgins (19) from Hawaii state that the heavy rainfall together with a continued cloudy, wet weather, are responsible for a small crop of poor quality mangoes. The same seems to be true in Guatemala and Mexico. In this connection, Nowell (26) says that with blossom blight "the loss may be small or may be great according to the conditions prevailing".

MeMrurran (25) says: "The production of good crops of mangoes in Florida and throughout tropical and subtropical zones generally is very definitely related to the weather conditions at blooming time. Large erops cannot be expected when the weather at this time is moist and showery. This may be due to some extent to imperfect pollination, but the trouble is chiefly caused in Florida by the anthracnose fungus (Colletotrichum gloeosporioides)." Our observations lead us to support that view.

I Color charncters throughout the paper are based on Ridway's "Color Standards and Nomenclature". 


\section{Arocado Anthracnose.}

The first report of the disease seems to be from Cuba by Cook. ${ }^{2}$ Torer (30) reports it from 'Trinidad in 1910. Later reports come from Porto Rico by Stevenson (38) in 1918, and from Florida by Stevens (37) in 1922. The disease appears as a blossom blight, fruit rot and a leaf spot. The effects and appearance of the disease on avocado blooms is similar to those of the blossom blight of the mango. Small black spots or specks appear on the small fiowers and result in their dropping. Flowers may also have their growth retarded and the young fruits may shed later. Blossom blight seldom occurs in Porto Rico. The shedding of the blossoms is almost cntirely due to imperfect pollination.

On the fruit the symptoms of this disease are as follows: Spots appear over the surface as small light-brown discoloration's of the skin of the fruit. They enlarge very rapidly, the color at the same time changing to olive-brown or black. This color corresponds to older growth while the younger growth (one-day old) is marked by a very light-brown ring or outer progressing zone. The fungus penetrates into the flesh and may even extend to the seed, which remains unaffected. There is a marvelous rapidity of rotting which makes the fruit useless. Our experiments with ripe and unripe fruit indieate that the fungus grows very slowly until the fruit begins to ripen. Inoculated unripe fruit is apparently unaffected until it begins to ripen; it is then destroyed in a very few days. The writer has found that the rotting is very prevalent in the market on fruits from which the stem has been removed. The Porto Rican farmer is not careful in the picking of the fruit, which he does by shaking the tree. This method gives many chances for inoculation of the fruit through wounds.

The symptoms of the disease on Guatemala varieties grown in Porto Rico are as follows: Small brown spots appear over the surface of the fruit. These spots grow slowly on unripe fruit, but on ripe fruit they enlarge and become sunken and black; eracking of the skin may oceur around the spots. If a fruit is opened, making the cut through a spot, the rotting will be seen to have progressed more deeply in the center of the spot than on the sides, thus resulting in a concave rotted region. The cracks which result from the invasion of the fungus hyphe open the way for the entrance of saprophytes which greatly aid in a rapid destruction of the fruit.

\footnotetext{
1. Dr. Mel. T. Conk has stated personaly to the writer that he fond the disense in Oubs during his stay at the Estacion Central Agronomica in the years 1902-190:
} 


\section{PART II}

CROSS-INOCULATION EXPERIMENTS, CULTURAL GHARACTERISTICS, AND MORPMOLOGY OF THE PATHOGLNES

\section{Cross-inoculation Experiments.}

Inoculation experiments have been conducted by various workers on different anthracnose organisms. Stoneman after working with anthracnoses (41), says that we must not depend too much upon results from cross-inoculations in the laboratory, since, under the conditions prevailing, the hosts act as culture media. Cobb (6b), Laubert (22) and Shear and Wood (31) are of the opinion that anthraenose fungi adapt themselves to a wide range of conditions. This makes careful experimentation necessary in order to make sure of the relations existing between the hosts and the parasites. Toro (43) conducted detailed studies with Glocosporium musarum Cke. $\&$ Mas. and arrived at a similar conclusion.

The writer has performed inoculation experiments with the various organisms on different hosts under laboratory and field conditions. The organisms were isolated from the different hosts and each was designated according to its host; $i . e$, the anthracnose fungus from the orange was marked, thus, $O$; that from the pomelo, $P$; that from the avocado, $\Delta v$.; from the mango, $M$; from the lime, $L$; and from the lemon, $L e$. As there were a number of cultures from each host, the culture number was given after the corresponding hest. Thus $L c 1$ was used to signify culture No. 1 from the lemon; $L 1$ to mean culture No. 1 from the lime; $O 1$, eulture No. 1 from the orange, etc. The source of all cultures is as follows: M 1-M 15; and N. 22-M 30 from ripe mangoes (native and imported varieties) from various places on the Island; M 16-MI 21, from blighted blossoms; P 1-P 7, young dropped pomelo fruits; P 8-P 10, pomelo flowers: O 1-0 10, young fallen orange fruits; Le 1-l he 5, young fallen lemon fruits (Chinese dwarf lemon); L 1, L, 2, I, 3, L 22, L 24-L 26, from lime fruit spots or cankers; L $4, \mathrm{~L}, 5, \mathrm{~L}, 19, \mathrm{~L} 21$, from lime withered twigs; L $6, L, 7, L, S$ and $L$ 14-L 18 , from lime leaf spots; L 9-I, 13, from lime thorn spots; and L, 23, from lime withered twigs from inoculation with $\mathrm{L}, 3$.

Isolations were made from fruit spots and rots mainly, in the case of eitrus hosts; however, isolations were also made from the withered tips of twigs, spotted leaves and blighted blossoms of citrus and from blighted mango blossoms as well.

In the fruit-inoculation experiments, all fruit were first washed 
in a 1: 1000 mereuric chloride solution and finally with sterile distilled water and then placed in moist chambers, which had been washed in the same solution. Needle-prick inoculations were practiced. All trials were made in triplicate. The results are given below:

Inoculations on Ripe Mangoes.-Inoculations with all cultures from mango, pomelo, orange, lemon and lime 1, 3, 9-12, and 23 produced large brown to black spots, characteristic of the disease on mango. All cultures from the lime except those given above produced slight discolorations of the tissue around the point of inoculation but these discolorations were not characteristic of the disease cn mango.

Inoculations on Avocados.-Inoculation on ripe fruits with Av. 1; $M 17,18$ and 20; P 1; 01 ; and lime cultures Nos. 1, 3 and 23, produced mummy-brown discolorations of the skin and rotting of the fruit. The same cultures when green fruits were inoculated citd not show any effects until the fruits began to ripen. Inoculations with lime cultures Nos. 2, 24, and 26 on both ripe and green fruits produced a slight discoloration around the point of inoculation.

Inoculations of Lime Twigs.-These twigs were inoculated with spores from natural lesions and with spores from cultures. The inoculations were made from a spore dilution in water applied to the twigs with an atomizer or a camel's hair brush. Some of the twigs were injured and others were left uninjured. They were covered with inanila bags. A fine mist of sterilized water was sprayed into all the bags every day after 5 p. m. The inoenlations were made with spores from acervuli on mango, avocado, pomelo and lime." Also with spores from cultures grown from acervuli on mango, avocado, and pomelo; also with spores from the acervuli on lime; spores from the lime cultures 1,2,3,23 and 24. All the above inoculations on lime twigs produced wither-tip and leaf spot.

Inoculations of Lime Fruits.- The lime fruits were inoculated with the same organisms and in the same manner as the lime twigs. The results in all cases were negative except in the case of fresh spores from the lime and those from culture L 2 and L 24 in which cases small, cankerous spots were produced.

Inoculation of Pomelo Scedlings.-These seedlings were inoculated in the same manner and with the same organisms as the preceding. In all cases a wither-tip and leaf spot were produced except when the fresh spores direct from the lime and those from cultures $\mathrm{L} 2$ and $\mathrm{L} 24$ were used; in which cases there was no reaction.

on Hango Twigs.-Needle-prick spore-spray inocnlations were 
made on the unopened buds of a new growth, and during rainy weather which insured a rapid growth of the host. Spores wero used from acervuli on avocado, mango, and pomelo, from cultures of $\mathrm{L} 1, \mathrm{~L} 3, \mathrm{~L} 23$, and $\mathrm{L} 2, \mathrm{~L} 24$ and $\mathrm{L} 26$.

The effect of all inoculations except those with L 2, L 24, and $L 26$ was as follows: Rapid dying of the young twigs causing small leaves of the young buds to shed comparatively early. Ten days after inoenlation, the dying of the twigs had progressed downward about $3 \mathrm{~cm}$. Infection is first manifested by slight browning or darkening of the adjacent tissues, then the twigs tum black (see fig. 3), The results with $\mathrm{L} 2, \mathrm{~L} 24$ and $\mathrm{L} 26$ were negative.

On Avocado Twigs.-The same general plan of inoculation and with the same organisms. was followed as with mango twigs. All inoculations showed negative results.

SUMMARY CONCERNING THE RESULTS OF INOCULATIONS ON POMELO SEEDLINGS, LWIE TWIGS, LIME FRUTTS, MANGO TWIGS, AVOCADO TWIGS, RIPE MINGOES; AND GREEN AND RIPE AVOCADOS

The results on these hosts tend to separate the cultures used in the foregoing inoculations into two groups: Group $l$, consisting of all cultures from the avocado, mango, pomelo, possibly orange and lime cultures Nos. 1, 3 and 23; Group II, consisting of cultures L $2, \mathrm{~L} 24$ and L 26.

It was especially noticeable that cultures which produce the anthaciose of mango, avocado, orange, pomelo, and some producing wither-tip of the lime in nature, were not able to produce the lime fruit spot or canker. This peculiar characteristic makes the above separation into groups more important. It is also apparent that these anthrocnose-producing fungi have no effect on avocado twigs. Mango twigs when tencler seem to be susceptible to the attack of Colletotrichum gloeosporioides. At least, this appears to be true under experimental conditions.

\section{Cultural Characteristics.}

The writer has made a careful study of the comparative behavior of the fungi under consideration on different media. A large variety of media have been carefully prepared and used in this work. AIl sugar media used were sterilized in the Arnold steam sterilizer; all other media in the autoclave at 20 pounds pressure for 30 minutes. Only 10 c.c. of the medium was put in each tube. All petri plates used were of the same size. All plates were poured the day previous 
to inoculation. Inoculations were made during the morning. They were made in triplicate for each culture and the tests were twice repeated. Growth was measured in centimeters in diameter at the end of seven days for solid media in petri plates. For liquid media growth was estimated by rapidity of growth and character of the substratum. Color changes were carefully noted and recorded. The results are given in the following pages. Tables and plates are here presented.

\section{Rate of Colony Growth.}

The growth of the colonies of each culture on 2 per cent nutrient glucose, 2 per cent nutrient saccharose, 2 per cent nutrient lactose, 2 per cent nutrient-clextrine, oat-meal, wheat-flour, and corn-meal agars was measured at the end of seven days and the results given as centimeters in diameter of colonies.

For convenience, all cultures from each host exhibiting a close relation in size in diameter of colony were grouped together. Table I includes the maximum, mean and minimum sizes of each group of colonies.

From an examination of Table $I$, it will be seen that there is a very sharp line of demarkation between Group 6, which includes cultures L $2, \mathrm{~L} 4-\mathrm{L} 8$, inclusive, I 14-L 22 , inclusive, and L 24-L 26 ; and all other group's under which all mango, avocado, pomelo, lemon, and orange cultures with $\mathrm{L} 1, \mathrm{~L} 3, \mathrm{~L}$ 9-L 13 , inclusive, and $\mathrm{L} 23$ : cultures. Thus, the means in all media for Group $6 \mathrm{run}$ from 4.255 . to $4.96 \mathrm{~cm}$. in diameter and minimum growth was 4 to $4.80 \mathrm{~cm}$. with the maximum growth being 4.40 to $5.60 \mathrm{~cm}$. in diameter; while measurements for the other groups taken as a whole are: mean, 6.28 to 8.04 ; minimum, 5.0 to 8.0 , and maximum, 7.0 to $8.5 \mathrm{~cm}$.

Therefore on the basis of colony size we will place tentatively, all cultures of Group 6, under one species and call it Glocosporium limeticolum Clausen, including cultures L 2, L 4-L 8 inclusive, L 14-L 21, inclusive, L 22, L 24-L 26 inclusive, and also L 4-L 8 inchusive. This will constitute Main Group 1 . All other cultures (L 1, L 3, L 23, all mango cultures, all avocado, pomelo, orange and ltmon cultures) under another species Collototrichum gloeosporioides. Penz. This will be Main Group II.

Growth character's (size of spores, zonation, color of both culture and substratum, character of mycelinm, etc.) of all cultures have been carefully observed with special reference to color behavior, on 
2 per cent glucose-nutrient agar, 2 per cent saccharose-nutrient agar, 2 per cent dextrine-nutrient agar, oat-meal agar, and corn-meal agar.

We have worked with carbohydrate media mainly since these afford a good working basis for the separation of strains and even species. Ravn (28) in studies on the genus Helminthosporium finds a relation between carbohydrate nutrient and blackness of the fungus. Stevens and Hall (34) have found good data on other fungi to support this view. Color phenomena in fungi have been studied and discussed in several paper's by Smith (32), Stewart and Hodgkiss (40) and Fedgecock (18). Relation of carbohydrate nutriment to color has also been established by Stevens (36). He found in his studies on Helminthosporium that the colony changes black in the region of the carbohydrate.

In our studies green or olive and brown discoloration of the substratum has been observed with a large number of cultures of the mango, avocado, orange, lemon, pomelo and a few of the lime cultures (Collctotrichum gloeosporioides). Most cultures from the lime pathogene (Glocosporium limetticolum. Clausen) show a light salmon-orange to apricot-orange or colors approximating these.

An attempt has been made to simplify the rendering of the results giving them in tabular form. All eultures which are alike in their effects on the media were grouped together in each particular nedium. In this way differences between cultures are easily noted and the separation of the two species C. glocosporioides Penz. and G. limetticolum Clausen is made possible withont great difficulty. The results are given for the glucose and corn-meal agars, in Tables II and IIr. The results and observations on the other media are - omitted for brevity.

Cultures which on one medium fall under a certain group may kelong under another group for some other medium. The relation between cultures which belong under the same species is thus established.

It is striking that cultures of $C$. gloeosporioides from mango, avocado, orange, pomelo, lemon and lime (Nos. 1, 3, 9, 10, 11, 12, 13 and 23 cultures) differ so much in cultural characters from those of $G$. limetticolum Clausen (lime cultures Nos. 2, 4, 5, 6, 7, 8, 14 . $15,16,17,18,19,20,21,22,24,25,26)$. A similar difference has been previously pointed out in relation to colony size.

Color behavior, character of mycelium and character of substratum of all mango, pomelo, orange, lemon and a few lime cultures Nos. 
$1,3,9,10,11,12,13,23$ ) are more or less similar. The arocado group is different. Our studies with the avocado cultures have not been very extensive, and therefore we are leaving them under the species Colletotrichum gloeosporioides Penz. Lime cultures Nos. 2, $4,5,6,7,8,14,15,16,17,18,19,20,21,22,24,25$ and 26 maintain a close relationship in the different characters of growth and develop. ment. The most peculiar character is the seanty mycelium in most of them.

The size of the acervuli is almost constant for the cultures of each species. The number of acervuli varies with the different cultures with both $C$. gloeosporioides and $G$. limetticolum. The acervuli of the former species are larger than those of the latter.

On the basis of growth character diseussed above we are holding Clausen's (5) division into two species to be correct. Of greatest importance are the following characters: Colletotrichum gloeosporioides: aerial mycelium white or dark, profuse, sometimes fluffy; of rapid development; acerruli numerous in most strains, large; substratum brown, green or olive or shades of these two latter colors. Glocosporium limetticolum: mycelium scanty in most cultures, white; acervuli small, numerous in most strains; substratum light salmonorange or apricot-orange.

\section{Effect of Reaction.}

All cultures were grown in bouillon of different acid and alkaline concentration; i. e., $+40,+45,-40,-45$, Fuller's scale. The same general method as for solid media was followed; i. e., triplicates of each culture on every medium. The tests were made twice.

Growth was recorded at the end of ten days and the rate or amount of growth given as,,,+++++++- , and no growth. Minch growth was expressed by +++ , fair growth by ++ , some growth by + , and very little growth or slightly noticeable was expressed by +- . The results are presented in Table IV. The +45 concentration is deleterious to all cultures and -45 to all except the avocado cultures. The $G$. limetticolum cultures do not grow in any of the four concentrations, so it seems probable that they must eease development at lower concentrations. The C. gloeosporioides rultures from the mango produce a fair growth in the +40 concentration, and those from the pomelo, orange, lemon, avocado and lime (L 1, L 3, L 9-L 13 inclusive, and L 23) some growth. Here again we have been able to verify Clausen's conclusion that there are two different species. 


\section{Size of Spores.}

To throw more light on the differential behavior of the different cultures as influenced by different nutrients, comparative measurements were made of spores from seven-day-old cultures in various media and from natural sourees.

Five hundred spores from each culture on glucose agar were measured for their lengths and widths. The spore-length table is cmitted as a matter of brevity.

A constant variation was found in length of spores of the different cultures while the margin of the width differences was very narrow. From our results it appears that spore size is not a very reliable basis for the determination of species. However, Toro (43) in his studies on banana anthracnose distinguishes eleven strains of Gloeosporium musarum Clke. \& Massee on the basis of spore size. Burger (2) finds differences in strains of Colletotrichum glocosporioides Penz. in regard to spore size. The same relation is established by La Rue and Barlett (21) with Pcstalozzia guepini Desm., Stackman and Piemeisel (33) with Puccinia graminis Eriks. \& Hern., Leach (23) with Collctotrichum lindomuthianum (Sace. \& Magn.), Brios and Cav. and Christensen (4) with Holminthosporium sativum (Pammel), King and Bakke.

Mean length of spores of cultures of Colletotrichum gloeosporioides and Glocosporium limetticolum on glueose agar are shown in Table $r$.

There is a range of $14.32 \pm 0.023$ to $22.51 \pm 0.0798$ microns. This means that with the former there is a wider range of mean length than with the latter and at the same time the shortest lengths are met with in Glocosporium limetticolum cultures.

It was found that many cultures approached each other in mean length of spores, which matle it possible to elassify them into groups on the basis of mean spore length. Table VI shows the classification.

It was also noted that there were many cultures with the same modal lengths so a elassification was prepared on this basis. This classification is given in Table VII.

The range of variability of spore lengths of a large majority of the cultures, judging from the preceding tables, is not very great and a correlation between this character and that of cultural cliaracteristics and host behavior has not been established.

Burger (2) in his investigations of variation within Collctotrichum. gloeosporioides found that many strains had the same mode for their spore lengths. Our findings verify this conclusion and at the same- 
time prove that variation also exists in the fungus Gloeosporium limetticolum. Cultures of Colletotriclurm gloeosporioides maintain a similar relation toward cultures of Gloeosporium limetticolum. Thus, L 1 which falls under the $C$. gloeosporioides group has the same modal length as $L 2$ of the $G$. limetticolum group, as shown by Table VII. Likewise, L 23 , L $9-\mathrm{L} 13$ inclusive, have the same mode as $\mathrm{I}_{\mathrm{i}}$ 14-L 21 ; the former belonging to $C$. gloeosporioides and the latter to $G$. limetticolum. The same relation exists between the cultures of C. gloeosporioides from different hosts as that occurring among individual cultures from the same host.

\section{Effect of Medium on Spore Length.}

In the study of the effect of media on the eultures it was soon observed that variability exists according to the medium. Spore length measurements were made from four media by the general pian followed in the preceding chapters, and the mean lengths calculated (see Table VIII).

The greatest mean length seems to occur on the dextrine and glucose agars for most cultures. The lowest mean lengths appeared on the saceharose and oat-meal agars. From these results it might appear that on starch media the spore length is shorter. However, we do not have enough evidence at hand to arrive at a definite conclusion.

\section{Lengths of Spores in Nature.}

Spores were measured from fruiting masses or acervuli on mango blossoms, mango fruits, avocado fruits, lime thom spots, lime leaf spots and lime twigs (see Table IX).

The length of spores from mango blossom varies from 13.19 to 19.04 microns with a mean of $16.87 \pm 0.036$ microns. The range of variation of spores from the fruit is wider than that of those from blossoms and the mean length is greater. The spores from the avocado have a minimum length falling under the range of minimum lengths of spores from the lime. The upper range or maximum length of spores is greatest for the spores from the lime twigs and leaf spots.

The measurements of spores obtained from pustules on lime thorns show some similarity to those of the spores from the mango and the avocado. This is further evidence that spotting on lime thorns is frequently caused by the fungus (C. gloeosporioides) causing the anthracnose diseases of those fruits. Our previous experiments and observations with cultures L 9-I 13 inclusive, obtained from lime thorn spots, show similar results. 


\section{Variation of Spore Widths.}

The range of variability in width of spores was not so great as that for the lengths. See Table $X$. There is a constant, although not great variation in the mean width of the various cultures. However, the minimum and maximum widths are common for a large number of cultures.

\section{Occurrence of setae.}

\section{MIOREHOLOGY}

Setre have been but rarely found under natural conditions. They were observed on llighted mango blossoms kept in a moist chamber and on citrus leaves, but not on lime fruits. Most cultures of $C$. glocosporioides produced sete in carbohydrate media while no setæ were ever produced by cultures of Glocosporitum limetticolum under similar conditions.

Rolfs (29) reports setze of C. glooosporioides on oranges but says that they are frequently absent on tender lime twigs, and on "lime fruits usually absent". Clausen (5) uses the absence of setæ in the pathogen to distinguish lime wither tip from that of other citrus fruits. Nowell (26) take's a similar position. Our observations prove that the absence or presence of setase will vary with the environment, and while not attaching much reliability to this characteristic, we are inclincd to support Clausen's (5) conclusion. Stoneman (41), Edgerton (21) and Shear and Wood (31) hold "That the sete are variable as to presence or absence and that they are not reliable morphological tharacters to use in separating genera."

\section{Conidiophores and Conidia.}

All cultures of $G$. limetticolum develop conidiophores which are light or almost hyaline, those of cultures of $C$. glocosporioides are slightly darker. Conidiophores from the avocado cultures of C. gloeosporioides seem to differ somewhat from those of the other eultures in shape and slightly in size and color. They are as a rule very light in color and broad at the middle with constrictions on both sides of the broad portion frequently occurring, and with pointed ends or even bases. They may be smaller than the conidiophores of the other cultures (see figs. 19, 20 and 21 ).

Clausen (5) uses the shape of spores as a strong point in distinguishing $G$. limetticolum fram C. glooosporioides. He describes the spores of the two species as follows:

"The conidia of the common wither-tip fungus have a peculiar very characteristic form. Typically one end is ratler rounded, the other end is blunt, but 
more or less obliquely trumeate, and there is slight eonstriction at the middle of the spore. The conidia of the pathogenic fungus have one or both ends more or less pointed with very little tendency toward constriction at the middle."

We have not found such differences existing between them on either spores from the natural source or those from cultures. The blunt end of the spores is just as true of $C$. gloeosporioides as of $G$. limetticolum (see figs. 8 and 9), and cases of the two ends being pointed have been found in both species (see figs. 12 and 13). Constriction of the spores although not frequent, occurs with both species (see figs. 10 and 11).

Vacuoles are more numerous and larger in the case of $G$. limetticolum, especially is this true of spores from cultures (see figs. 14 and 16). The medium seems to have an important relation on spore shape and form. All forms have been noted with both C. gloeosporioides and $G$. limetticolum in difierent media. Some are constricted at various places, others are very long and thin, while others are short and wide. Still others are very wide at one end and very narrow at the other, being more or less fiask-shaped (see figs. 17 and 18).

The character of conidia still remains a rather doubtful or confusing basis in the distinction between Collototrichum glocosporioides. and Glocosporium limetticolum.

\section{SUMMARY AND CONCLUSIONS}

(1) Colletotrichum glocosporioides Penz. appears to be the cause of the anthracnose diseases of mango, orange, grapefruit, lemon, avocado, and sometimes of lime.

(2) Lime wither-tip may be caused by either C. gloeosporioides or Glocosporium limetticolum Clausen.

(3) Colletotrichum glocosporioides Penz. frequently causes spotting of lime blossoms and the wither-tip. It is also the cause of the spots on lime thorns. The latter is demonstrated by cultures L 9 It 13 , inclusive, which behaved like other C. gloeosporioides cultures and very distinet from cultures of $G$. limetticolum.

(4) Glocosporium limetticolum Clausen is the cause of wither-tip. and leaf spot of limes.

(5) $G$. limoticolum appears to be the only cause of fruit canker or fruit spot of limes.

(6) Under artificial conditions the various cultures of $C$. gloeosporioides and $G$. limetticolum exhibit distinet cultural characteristics. 
(7) Cultures from the avocado differ somewhat from cultures obtained from other hosts in cultural characteristies. The difference may not furnish enough evidence for their separation into a new speeies.

(8) There are such differences between most cultures from the lime and all cultures from the other hosts that Clausen's (5) separation of the former into a distinct species appears to be justified.

(9) The four most salient growth characters in which cultures of $C$. gloeosporioides varied from cultures of $G$. limetticolum or snch eultures among themselves are: (a) size, number, and arrangement of acervuli; (b) color of acervuli and substratum; (c) eharacter of aerial mycelium; $(d)$ size of colonies.

(10) C. gloeosporioides ean resist slightly more acid or alkaline coneentrations than $G$. limetticolum.

(11) Setre are occasionally present in C. gloeosporioides and absent in $G$. limetticolum.

(12) Variation in spore size is induced by the culture medium.

(13) There is great morphological similarity between G. limetticolum and $C$. gloeosporioides.

(14) Environment induces variation in form and shape of spores.

(15) The character of conidia appears to be rather uncertain for distinguishing between Gloeosporium limetticolum and Colletotrichum gloeosporioides.

The writer wishes to acknowledge his deepest appreciation to Dr. Mel. T. Cook, Chief of the Division of Botany and Plant Pathology, under whose direction this work has been conducted; whose neverfailing encouragement and advice together with much valuable and helpful eriticisms and suggestions have made the preparation of this paper possible.

\section{LITERATURE CITED}

1. Bessey, E. A. Report of Plant Diseases. Proc. 21st. Anu. Meet., Florida St. Hort. Soc., 1908: 97. 1908.

2. Burger, O. F. Variation in Colletotrichum glocosporioides. Jour. Agr., Res. 20: 723-736. 1921.

3. Cardin, P. P. Bloom Blight of Mango in Cuba. The Cuban Review, 8: 28-29. 1910.

4. Christensen, J. J. The parasitism of Helminthosporium sativum. Univ. Mimmesota Expt. Station Tech. Bull. 11. 1922.

5. Cunusen, R. E. A New Fungus Concerned in Whither-tip of Varieties of Citrus Medica, Phytopath. 2: 217-235. 1912.

6a. Coвb, N. A. (Notes on Diseases of Plants, N. S. W. Agr. Gaz. 1894: $379-390.1894$. 
6b. Coвb. N. A. Letters on the Diseases of Plants. New South Wales Agric. Dept. Misc. Pub. 666 (2nd. series) 1-27. 1904.

7. Collins, G. N. The Mango in Porto Rico. U. S. Dept. of Agrie., B. P. I. Bull. 28, 1903.

8. Cook, M. T'. Primer Informe Anual de la Estación Central Agronómica de Cuba. 1906: 152-153. 1907.

9. Cook, M. T. LND HorNe, W. T. Insects and Diseases of the Orange, Est. Cent. Agron. Cuba. Bul. 9. 1908.

10. Cock, M. T. Diseases of Tropical Plants. MacMillan Co. 1913. 1913.

11. DugGar, B. MI. Fungus Diseases of Plants. Ginn \& Co. 1909.

12. Edgerton, C. W. The Physiology and Development of Some Anthraenoses. Bot. Gaz. 45: 367-408. 1908.

13. Essig, E. O. Wither-tip of Citr'us Trees (Colletotrichum gloeosporioides Penzig). Pomona Coll. Jour. Econ. Bot. 1: 25-26. 1911.

14. Fawcer, G. L. Annual Report of Porto Rico Agricultural Experiment Station. 1909: 35-36. 1910.

15. FAFCET, H. S. Mango Bloom Blight (Gloeosporium mangiferae). Florida Agric. Expt. Sta. Rept. 1906: 25. 1907.

16. Fawcet, W. and Ilarris, W. The Mango. Bul. Bot. Dept., Jamaica, N. S. 8: 161-167. 1901.

17. Fulton, H. R. Relative Susceptibility of Citrus Varieties to. Attack by Gloeosporium limetticolum Clausen. Jour. Agric. Res. 30: 629-635. 1925.

18. HengEcock, G. G. Studies upon Some Chromogenic Fungi which Discolor Wood. Rept. Nissouri Bot. Gard. 17: 59-117. 1906.

19. Higgins, J. E. The Mango in Hawaii. Hawaii Agric. Expt. Sta. Bul. 12. 1906.

20. Huse. H. H. Anthracnose of the Pomelo. Florida Agrie. Expt. Sta. Bul. 74. 1904.

21. La Rue, C. D. and Barletre, N. H. A Demonstration of Numerous Distinct Strains Within the Nominal Species Pestalozzia guepini Desm. Am. Jour. Bot. 9: 79-92. 1922.

22. Lnubert, R. Die Gloeosporiumfäule der Banane und die Gloeosporium und Phyllosticta-Blattfleckenkrankheit des Ffeus. Gartenflora 59: 409-415. 1910.

23. Leach, J. G. The pasasitism of Colletotrichum Lindomuthianum. Univ. Ninnesota Expt. Sta. Teeh. Bul. 14. 192\%.

24. Massee, G. Diseases of Cultivated Plants and l'rees. 1914.

25. MoMlurran, S. M. The Anthracnose of the Mango in Florida. U. S. Dept. of Agric. B. P. I. Bull. 52. 1914.

26. Noweld, W. Diseases of Crop Plants in the Lesser Antilles. West India Committee (no date).

27. Popenoe, W. Mamual of Tropical and Subtropical Fruits. 1920.

28. RavN, K. Nogel Helminthosporiumarter og de af. dem fremkaldte Sygdomme hos Byg og Haver. Bot. Tid. 23: 101-327. 1900 . 
29. Rolfs, P. H. Wither-tip and other Diseases of Citrus Trees and Fruits Caused by Colletotrichum gloeosporioides. U. S. Dept. Agric. B. I. Bull. 52. 1914.

30. Roren, J. P. Anmual Report of the Myeologist. Board of Agric., Trinidad. 1910: 7 .

31. Shenr, C. L. AND WOOD, A. K. Studies on Fungous Parasites Belonging to the Genus Glomerella. U. S. Dept. Agr. B. P. I. Bull. 252. 1913.

32. Surrte, E. F. Wilt Disease of Cotton, Watermelon, and Cowpea. U. S. Dept. of Agric. Div. Veg. Phys. and Path. Bul. 17. 1899.

33. Stackman, E. C. and Piemeised, F. J. Biologic Forms of Puccinia graminis on Cereals and Grasses. Jour. Agric. Res. 10: 429-495. 1917.

34. Strevens, F. L. AND Hald, J. G. Variation of Fungi due to Environment . Bot. Gaz. 48: 47-71. 1909.

35. Strvens, F. I. The Fungi which Cause Plant Disease. MacMillan. 1913.

36. Strevens, F. L. The Felminthosporium Foot-rot of Wheat, with Observations on the Morphology of Helminthosporium and on the Occurrence of Saltation in the Genus. Illinois Dept. Reg. Ed. Div. Nat. Surv. 14: 77-184. 1922.

37. Stevens, H. E. Arocado Diseases. Florida Agric. Expt. Sta. Bul. 161. 1922.

38. Srevenson, J. A. Citrus Diseases of Porto Rico. Jour. Dept. Agrie. Porto Rico 2: 43-123. 1918.

39. Srevenson, J. A. A Check List of Porto Rican Fungi and a Host Index. Jour. Dept. Agrie. Porto Rico, 2: 125-264. 1918.

40. Stewart, F. C. and Hongkiss, H. E. The Sporotrichum Budrot of Carnation and the Silvertop of June Grass. New York (Geneva) Agr. Expt. Sta. Tech. Bul. 1. 1908.

41. Stomman, B. A Comparative Study of the Development of Some Anthracnoses. Bot. Ga\% 26: 69-120. 1898.

42. Thomas, H. E. Anmual Report. Porto Rico Agrie. Expt. Sta. 1912: 28-30. 1913.

43. Toro, R. A. Studies on Banana Anthraenose. Journ. Dept. Agric. Porto Rico, 6: 1-28. 1924.

44. WInston, J. R. T'ear-stain of Citrus Fruit. U. S. Dept of Agric. Bul. 924. 1921. 
TABLE I.

Separation of Cultures of $C$. glocosporioides and G. limetticolum on the Basis of Colony Size in Oentimeters in Diameter, at the end of seven days

\begin{tabular}{|c|c|c|c|c|c|c|c|c|c|c|c|c|c|c|c|c|c|c|c|c|c|}
\hline \multirow[b]{2}{*}{ Cultures In Each Group } & \multicolumn{3}{|c|}{$\begin{array}{c}2 \not{a} \\
\text { Glucose } \\
\text { agar }\end{array}$} & \multicolumn{3}{|c|}{$\begin{array}{c}\text { Snce arose } \\
\text { agnr }\end{array}$} & \multicolumn{3}{|c|}{$\begin{array}{l}2 f \\
\text { Dexirine } \\
\text { agrar }\end{array}$} & \multicolumn{3}{|c|}{$\begin{array}{l}2 \% \\
\text { Lactose } \\
\text { agar }\end{array}$} & \multicolumn{3}{|c|}{$\begin{array}{l}\text { Wheatmeal } \\
\text { agar }\end{array}$} & \multicolumn{3}{|c|}{$\begin{array}{l}\text { Cornmeal } \\
\text { agar }\end{array}$} & \multicolumn{3}{|c|}{$\begin{array}{l}\text { Oatineal } \\
\text { agar }\end{array}$} \\
\hline & $\underset{\Xi}{\stackrel{\Xi}{\Xi}}$ & 荵 & 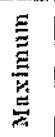 & 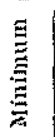 & 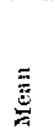 & 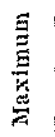 & 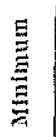 & 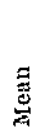 & $\underset{\Xi}{\Xi}$ & $\begin{array}{l}\text { 节 } \\
\stackrel{\Xi}{\Xi} \\
\text { 范 }\end{array}$ & $\stackrel{\Xi}{\tilde{E}}$ & $\underset{\Xi}{\stackrel{E}{\Xi}}$ & $\underset{\Xi}{\Xi}$ & $\underset{\tilde{E}}{\tilde{E}}$ & 罡 & $\stackrel{\Xi}{\Xi}$ & 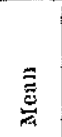 & 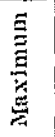 & $\underset{\Xi}{\stackrel{\Xi}{\Xi}}$ & 莺 & $\underset{\Xi}{\stackrel{\Xi}{\Xi}}$ \\
\hline 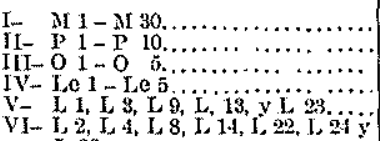 & $\begin{array}{l}6.0 \\
6.0 \\
7.0 \\
7.8 \\
7.8\end{array}$ & $\begin{array}{l}7.08 \\
6.89 \\
7.32 \\
7.98 \\
7.75\end{array}$ & $\begin{array}{l}8.0 \\
8.0 \\
7.6 \\
8.1 \\
8.0\end{array}$ & $\begin{array}{l}6.7 \\
6.8 \\
7.0 \\
8.0 \\
8.0\end{array}$ & $\begin{array}{l}7.61 \\
7.24 \\
7 . .10 \\
8.02 \\
8.10\end{array}$ & $\begin{array}{l}8.2 \\
7.8 \\
7.6 \\
8.1 \\
8.3\end{array}$ & $\begin{array}{l}5.5 \\
5.8 \\
7.0 \\
7.7 \\
7.1\end{array}$ & $\begin{array}{l}7.12 \\
6.90 \\
7.84 \\
7.92 \\
i .75\end{array}$ & $\begin{array}{l}8.0 \\
7.8 \\
8.5 \\
8.1 \\
8.0\end{array}$ & $\begin{array}{l}6.0 \\
5.0 \\
7.0 \\
7.8 \\
7.4\end{array}$ & $\begin{array}{l}7.53 \\
7.18 \\
7.20 \\
8.04 \\
7.90\end{array}$ & $\begin{array}{l}8.2 \\
8.0 \\
7.5 \\
8.2 \\
8.1\end{array}$ & $\begin{array}{l}5.9 \\
7.0 \\
6.5 \\
7.5 \\
7.7\end{array}$ & $\begin{array}{l}7.43 \\
7.60 \\
7.32 \\
7.7 \cdot 1 \\
7.86\end{array}$ & $\begin{array}{l}7.9 \\
7.8 \\
7.8 \\
7.8 \\
8.0\end{array}$ & $\begin{array}{l}6.1 \\
7.0 \\
7.8 \\
7.8 \\
7.8\end{array}$ & $\begin{array}{l}7.19 \\
7.74 \\
7.90 \\
8.00 \\
7.95\end{array}$ & $\begin{array}{l}7.6 \\
8.0 \\
8.0 \\
8.2 \\
8.0\end{array}$ & $\begin{array}{l}5.8 \\
7.0 \\
6.0 \\
7.8 \\
5.2\end{array}$ & $\begin{array}{l}7.21 \\
7.36 \\
6.28 \\
7.80 \\
7.60\end{array}$ & $\begin{array}{l}8.0 \\
7.7 \\
7.0 \\
7.8 \\
8.0\end{array}$ \\
\hline 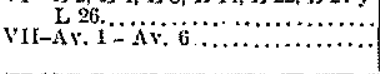 & $\begin{array}{l}4.0 \\
7.7\end{array}$ & $\frac{4.71}{7.75}$ & $\begin{array}{l}5.0 \\
7.8\end{array}$ & $\begin{array}{l}\mathbf{f} .1 \\
7.8\end{array}$ & $\begin{array}{l}4.87 \\
7.98\end{array}$ & $\begin{array}{l}5.1 \\
8.2\end{array}$ & $\begin{array}{l}4.1 \\
7.5\end{array}$ & $\begin{array}{l}1.25 \\
7.600\end{array}$ & $\begin{array}{l}4.4 \\
7.7\end{array}$ & $\begin{array}{l}4.0 \\
7.0\end{array}$ & $\begin{array}{l}4.49 \\
7.15\end{array}$ & $\begin{array}{l}5.1 \\
7.3\end{array}$ & $\begin{array}{l}1.2 \\
7.9\end{array}$ & $\begin{array}{l}1.85 \\
7.36\end{array}$ & $\begin{array}{l}5.0 \\
7.0\end{array}$ & $\begin{array}{l}4.8 \\
7.4\end{array}$ & $\begin{array}{l}4.96 \\
7.47\end{array}$ & $\begin{array}{l}5.1 \\
7.5\end{array}$ & $\begin{array}{l}4.1 \\
7.6\end{array}$ & $\begin{array}{l}4.68 \\
7.73\end{array}$ & $\begin{array}{l}5.6 \\
7.8\end{array}$ \\
\hline
\end{tabular}




\section{TABL II}

Characters of Growth of All Cultures on 2 Per Cent Nutrient Glucose Agar. The cultures arranged into groups according to character of growtl.

GROUP I

M. 1 , M 2, M 3, M 4, M 5, M 6, M. 20, M 21, M 16, M 17.

GROUP II

M 7-M 15, M 22-M 27.

GROUP III

P 2, P 3,

$\mathrm{P} 4, \mathrm{P} 6$,

P 7, P 9, P 10.

GROUP IV

P 1. P 8,

P 5, O 1,

O 3m0 5, Av. 6 .

GROUP V

02 ,

LE 1-Le 5.

GRODP VI

L 5-L 8 ,

L 22, L 24,

L 25 , L 4 ,

L 2.

GROUP VII

L 14-L 21,

GROUP VIII

L $3, \mathrm{~L} 23$,

L 1 ,

L $9-\mathrm{L} 13$.

GROUP IX

Av. 1-Av, 6.

GROUP $\mathrm{X}$

MI $18-19$

GROUP XI

L 26 .
Acervuli large, numerous, in zones; briele-red in color; substratum: zones of dark grecnish-olive with some brick-red marks underlying the masses of acervuli; older growth underlaid by mars brown color; myeelium profuse in long thrends; white in some colonies; grayish or dark in others.

Acervuli large, numerous, zoned or not, all shades of color from yellowish olve to olive or darto-greenish-olive. Brown spots underlie some of the acervuli misses. Acrial mycelium profuse, dull white to dark in color. In some eolonies the acervuli are salmon in color with brownish-olive or mummy brown substratum.

Acervuli large, numerous, zoned or not, all shades of color from light-ochraceous-buff with olive nuarkings to ochraccous-buff with substratum underneath the acervuli of a cinnamon-rufous color and brownish-olive in the imer zones. The medium under the old growth changes in some colonies to almost dan brown or black. Mycelium profuse, whitish.

Acervuli large, numerous, zoned, pale ochraceous-salmon. Color of substratum underneath the acervuli is forruginous. Concentric ferruginous markings on colony. Aerial mycelium profuse.

Acervuli large, numerous, zoned or not, ochraceous-salmon; substratum shows ochraceous-salmon discoloration and muel cin. namon brown or even ochraceous buff with cinnamon-brown. Mycelium profuse, $\mathrm{O}_{2}$ more profuse than the others.

Acervuli small, numerous or few, not zoned, light-salmon or. ange, mycelium in form of very short whitish threads.

Aeervuli small, numerous, not zoned, substratum unelanged; profuse, dull white.

Acervuli large, numerous, more or less zoned, flesh color. Sub. stratum: ferruginous to Kaiser-brown with brownish-olive zones or flesh-ocher. Aerial mycelium profuse whitish dull.

Acervuli large numerous in old eolonies, in young colonies only in eentral portion, rufous. Masses of spores borne on the aerial mycelium around the center of the colony are grenadine pink to light-salmon-orange. Acervuli zoned or not. Mycelium white (snow); profuse, floceose, the long tufts radially arranged. The power for mycelial growth is remarkable, the tufts reaching the top dish and spreading under it.

Acervuli large, numerous, perfeet zonation, apricot-orange in color. Nearly always lave central portion of colony of a gray mycelium. Tufts of gray mycelium also occur throughout the young growth.

Acervuli small; numerous, apricot orange in color; central portion of colony is bluish-black. 
TABLE III

Growth Characters of All Cultures on Corm-Meal Agar. They are arranged according to these characters.

GROUP $I$

M 7-M 11, L 13 , L. 1 . GROUP II M 10.

GROUP III P 1-P 4.

GROUP IV P 5-P 10, 01 .

GROUP V

Le 1-Le 5 .

GROUP VI

L $\tilde{5}-\mathrm{L} S$.

GROUP VII

L 9-1 12,

L $22, \mathrm{~L} 24$.

IROUP VIII

L 3, L 23.

GROUP IX

I 14-I 21 .

GROUP $\mathrm{X}$

Av. 1-Av. 5 .

GROUP XI

L $25, \mathrm{~L} 26$.
Acervuli large, numerous, zonation not distinct, salmon; substratum: dark grayish-olive; mycelium white, dark or gray, profuse.

Acervuli large, numerous, rufous or apricot-orange. Substratum: rufous or apricot-orange along the edge of colony dark grayish-olive; myeelium fair, dark.

Acervuli large, numerous, ferruginous; substratum grecnish. alive; myeclium moderate, white or dark.

Acervuli large, numerous, light salmon-orange or flesh-ocher; myeclium seanty in some eultures, profuse in others.

Acervuli large, numerous, more or less zoned, ochraccous sal. mon; substratum: ochrtccous-salmon; mycelium moderate to profuse, white (dull).

Acervuli small, numerous, not soncd, flesh-ocher; substratum: ocher-red; aerial myeelium occurring as short threads, white.

Accrvuli large, numerous, slightly zoned, flesh ocher; substra. tum flesh-ocher, green under acervuli; aerial myeelium oceurring as long threads.

Acervuli large, numerous, not zoned; rufous; in streaks over surfate of colony. Substratum: rufous; mycelium little, white.

Acervuli small, numerous, no zonation, flesh ocher; substratum: fesh-ocher to ocher-red. Small masses of mycelium, white.

Acervuli large, few, apricot-orange, for the most part in a large mass in the center of the colony, otherwise seattered in small numbers througlout the surface or in zones; substratum: surface line dark greonish-olive, more pronouneed in some cultures than in others; myeclium either in the form of a large, white mass around the center of the colony or white, floccose, sometimes fluffy.

Acervuli small, numerous, not zoned, flesh ocher, except a central green portion; substratum: bluish central portion, ocherred outsile it; aerial mycelium in form of very short threads. 
TABLE IV

Shows Effect of Reaction. Growth on Bonillon of Different Acid and Alkaline Reaction

\begin{tabular}{|c|c|c|c|c|}
\hline Culture & $\begin{array}{c}+40 \\
\text { Fuller's scale }\end{array}$ & $\begin{array}{c}+45 \\
\text { Puller's Scate }\end{array}$ & $\begin{array}{c}-40 \\
\text { Fuller's scale }\end{array}$ & $\begin{array}{c}-45 \\
\text { itulter's Scale }\end{array}$ \\
\hline $\mathrm{M} 1-\mathrm{M} 30, \ldots \ldots \ldots$ & ++ & No srowth & + & No growth \\
\hline $\mathrm{l}^{\prime} 1-\mathrm{g} 10 \ldots \ldots \ldots$ & $\div$ & No growtin & + & No growth \\
\hline $01-0 \quad 5 \ldots \ldots \ldots$ & + & No growth & $\begin{array}{l}\text { Sumon tacervili } \\
\text { on the surface }\end{array}$ & No growtl \\
\hline Le 1 - le 5 ........... & + & No growth & + & No growth \\
\hline 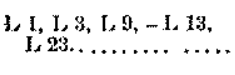 & + & No growth & + & No growth \\
\hline $\begin{array}{l}L 2, \mathrm{~L}, \mathrm{~L}-8, \mathrm{~L}, 14-\mathrm{L} \\
\mathrm{2}, \mathrm{L}, 24-20 \ldots \ldots \ldots\end{array}$ & No growth & No growth & No growth & No growtil \\
\hline Av. 1-Av. 6. & + & No growti & $\underset{\substack{\text { Large numerged cols } \\
\text { sties } \\
\text { nies }}}{+++}$ & $*-$ \\
\hline
\end{tabular}




\section{TABLE V}

Showg Mean Juengths in Microns of Spores of Cultures of $C$. gloeosporioides. and G. limetticolum on 2 per cent Glucose Agar

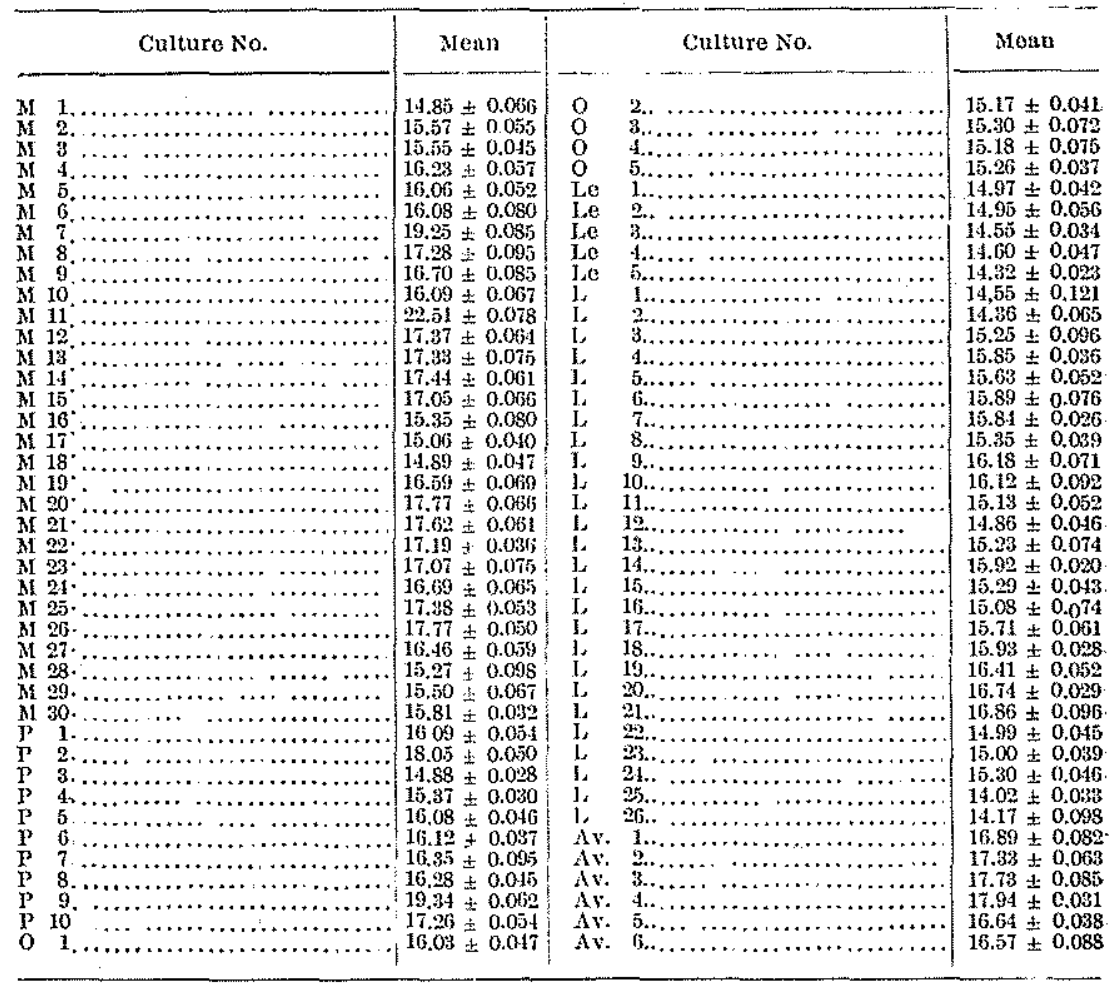

\section{TABLE VI}

Separation of Cultures of $C$. gloeosporioides and G. limetticolum into Groups According to Mean Lengths of Spores in Microns

\begin{tabular}{|c|c|c|}
\hline Group & Cultures & $\begin{array}{l}\text { Range mean } \\
\text { length } \\
\text { in microns }\end{array}$ \\
\hline 1 & 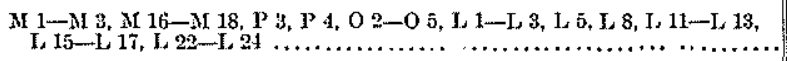 & $14.85-15.816$ \\
\hline II & 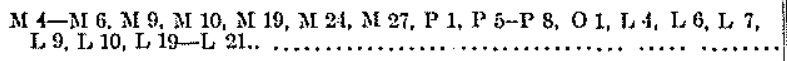 & $15.839-16.861$ \\
\hline III & MI 8, M $12-\mathrm{M} 15$, il $20-\mathrm{MI} 23, \mathrm{M} 25, \mathrm{M} 26, \mathrm{P} 10, \mathrm{Av}, 1-\mathrm{Av}, 3 \ldots \ldots \ldots \ldots$ & $16.890-17.794$ \\
\hline IV & 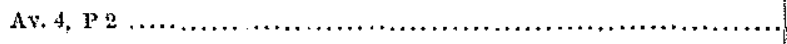 & $17.94-18.90$ \\
\hline $\mathrm{V}$ & M $7, P 9 . . \quad \ldots$. & $19.257-20.250$ \\
\hline VI & 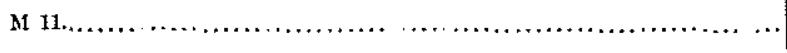 & $21.50-22.511$ \\
\hline
\end{tabular}


TABLE VII

Classiffcation of Cultures into Groups According to Modal Spore Length

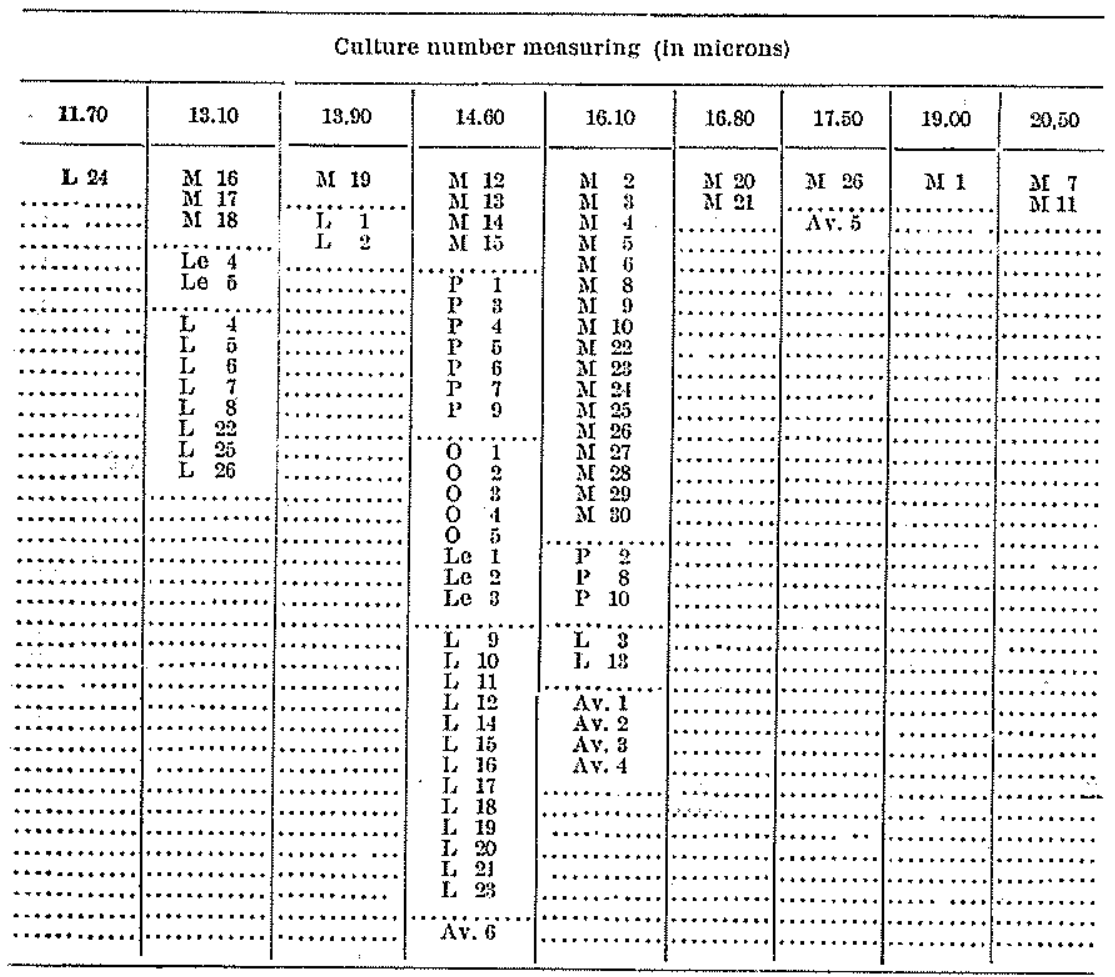

TABLE VIII

Shows Effect on Medium on Spore Mean Length (in Microns)

\begin{tabular}{|c|c|c|c|c|}
\hline Strain No. & $\begin{array}{l}2 \% \text { Glucose } \\
\text { agar }\end{array}$ & $\begin{array}{c}\text { 2\% Saccharose } \\
\text { ngar }\end{array}$ & $\begin{array}{l}\text { 2\% Doxtrine } \\
\text { agar }\end{array}$ & $\underset{\text { agar }}{\text { Oatmoal }}$ \\
\hline 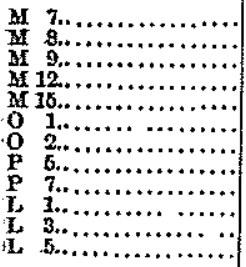 & $\begin{array}{l}19.25 \pm 0.085 \\
17.28 \pm 0.095 \\
16.70 \pm 0.085 \\
17.37 \pm 0.061 \\
17.05 \pm 0.066 \\
16.08 \pm 0.047 \\
16.17 \pm 0.041 \\
16.08 \pm 0.046 \\
16.35 \pm 0.005 \\
14.55 \pm 0.121 \\
15.25 \pm 0.006 \\
10.63 \pm 0.052\end{array}$ & $\begin{array}{l}16.08 \pm 0.047 \\
16.23 \pm 0.050 \\
18,31 \pm 0.063 \\
16.01 \pm 0.071 \\
16.95 \pm 0.043 \\
15.17 \pm 0.030 \\
16.6 \pm 0.022 \\
13.98 \pm 0.040 \\
14.32 \pm 0.021 \\
16.51 \pm 0.057 \\
14.33 \pm 0.099 \\
16.21 \pm 0.034\end{array}$ & $\begin{array}{l}16.92 \pm 0.027 \\
18.09 \pm 0.024 \\
19.49 \pm 0.060 \\
16.62=0.053 \\
18.05 \pm 0.014 \\
15.80 \pm 0.027 \\
14.00 \pm 0.036 \\
15.08=0.019 \\
15.03 \pm 0.052 \\
16.72 \pm 0.020 \\
15.38 \pm 0.019 \\
18.02 \pm 0.031\end{array}$ & $\begin{array}{l}16.51 \pm 0.031 \\
15.60 \pm 0.048 \\
15.32 \pm 0.072 \\
18.05 \pm 0.055 \\
16.72 \pm 0.065 \\
14.25 \pm 0.071 \\
14.48 \pm 0.020 \\
14.24 \pm 0.070 \\
14.27 \pm 0.028 \\
16.07 \pm 0.037 \\
13.66 \pm 0.012 \\
16.89 \pm 0.064\end{array}$ \\
\hline
\end{tabular}


Table IX

Length Measurements in Microns of Fresh Spores of C. glocosporioides and G. limetticolum

\begin{tabular}{|c|c|c|c|}
\hline Source of Fresh Spores & Mraximum & Mean & Minimum \\
\hline 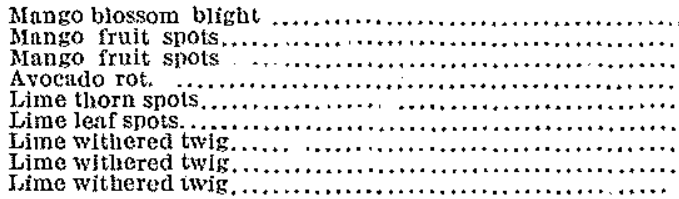 & $\begin{array}{l}19.04 \\
22.00 \\
23.45 \\
20,50 \\
16.12 \\
43.98 \\
24.92 \\
26.39 \\
23.45\end{array}$ & $\begin{array}{l}16.81 \pm 0.085 \\
16.12 \pm 0.049 \\
17.50 \pm 0.029 \\
19.04 \pm 0.032 \\
14.66 \pm 0.021 \\
14.60 \pm 0.099 \\
13.29 \pm 0.066 \\
14.65 \pm 0.035 \\
16.12 \pm 0.035\end{array}$ & $\begin{array}{l}13.19 \\
11.73 \\
13.19 \\
11.73 \\
11.78 \\
11.78 \\
18.19 \\
10.26 \\
10.26\end{array}$ \\
\hline
\end{tabular}

TABLE $X$

Maximum, Mean and Minimum Widths in Microns of Cultures of C. glocosporioides and G. limeticolum

\begin{tabular}{|c|c|c|c|}
\hline Culture & Maximum & Mean & Minimum \\
\hline 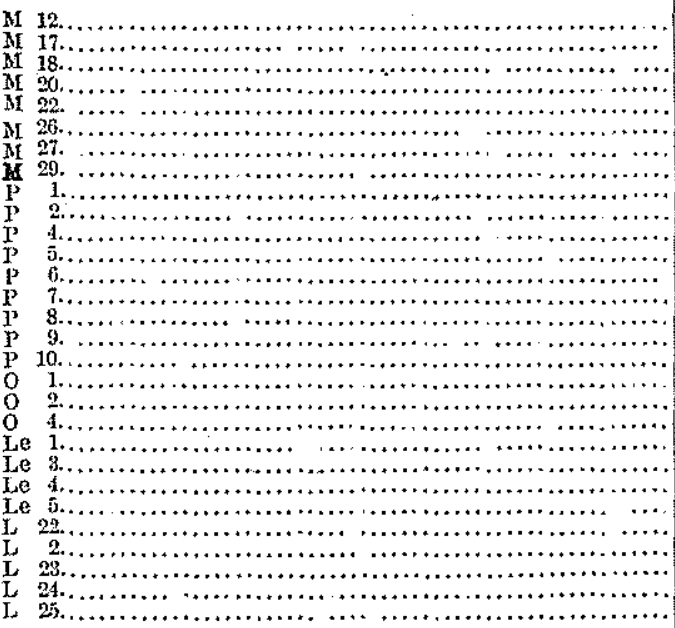 & $\begin{array}{l}5.42 \\
5.57 \\
5.72 \\
5.72 \\
5.57 \\
5.42 \\
5.42 \\
5.42 \\
5.42 \\
5.42 \\
5.42 \\
5,57 \\
5.42 \\
5.57 \\
5.57 \\
5.57 \\
5.72 \\
5.57 \\
5.42 \\
5.57 \\
6,16 \\
5.18 \\
5.49 \\
5.42 \\
5.42 \\
5.57 \\
5.57 \\
7.33 \\
6.16\end{array}$ & $\begin{array}{l}4.40 \pm 0.017 \\
4.61 \pm 0.081 \\
4.43 \pm 0.062 \\
4.62 \pm 0.089 \\
4.69 \pm 0.027 \\
4.48 \pm 0.069 \\
4.37 \pm 0.078 \\
4.45 \pm 0.088 \\
5.13 \pm 0.080 \\
4.54 \pm 0.090 \\
4.41 \pm 0.066 \\
5.16 \pm 0.031 \\
4.69 \pm 0.099 \\
4.25 \pm 0.045 \\
4.40 \pm 0.086 \\
4.48 \pm 0.035 \\
5.24 \pm 0.096 \\
4.65 \pm 0.049 \\
5.18 \pm 0.029 \\
4.38 \pm 0.041 \\
4.47 \pm 0.087 \\
4.46 \pm 0.075 \\
4.58 \pm 0.039 \\
4.54 \pm 0.035 \\
4.29 \pm 0.044 \\
4.46 \pm 0.037 \\
4.55 \pm 0.086 \\
4.98 \pm 0.027 \\
4.92 \pm 0.018\end{array}$ & $\begin{array}{l}3.22 \\
3.66 \\
4.10 \\
4.10 \\
4.10 \\
3.66 \\
3.22 \\
2.98 \\
3.66 \\
3.61 \\
4.10 \\
4.40 \\
3.22 \\
2.98 \\
4.10 \\
3.66 \\
4.10 \\
4.10 \\
3.22 \\
3.22 \\
4.10 \\
3.60 \\
4.10 \\
4.10 \\
2.98 \\
3.22 \\
3.61 \\
3.66 \\
3.66\end{array}$ \\
\hline
\end{tabular}




\section{PLATES I-VI}




\section{LEGEND FOR PI,ATE I}

Fraune 1.-Mango leaf showing spots caused by Oolletotrichum glososporioides.

FIGUR: 2.-Blight of lime blossoms produced by Glocosporium limetticolum. (A) Leaions on the petals. Young fruits (B) with diseased stigmas shown in black $(1,2)$; normal young fruit (3).

Fraure 3.-Withered twigs of the mango caused by inoculations with $O$. glocosporioides. a, Mango cultures; $b$, Avocado cultares; c, Pomelo cultures; $a$, Orange cultures.

Figune 4.-Setro of $O$. Dloeosporioides on $a$, Oat-meal agar; $b$, Nutrient agar; $c$, Cook'b No. 11 agar; d. Arocado cultures on Oook's No. 11 agar.

Froune 5.-Oross-section of a pustule of $O$. oloeosporioides on lime stigma. Shows coni. diophores, conidia and setw.

Fraune 6.-Oross-section of pustule of 0 . gloesporioides on the lime.

Frgune 7 .-Wither-tip of the lime caused by $G$ limetticolum.

52 


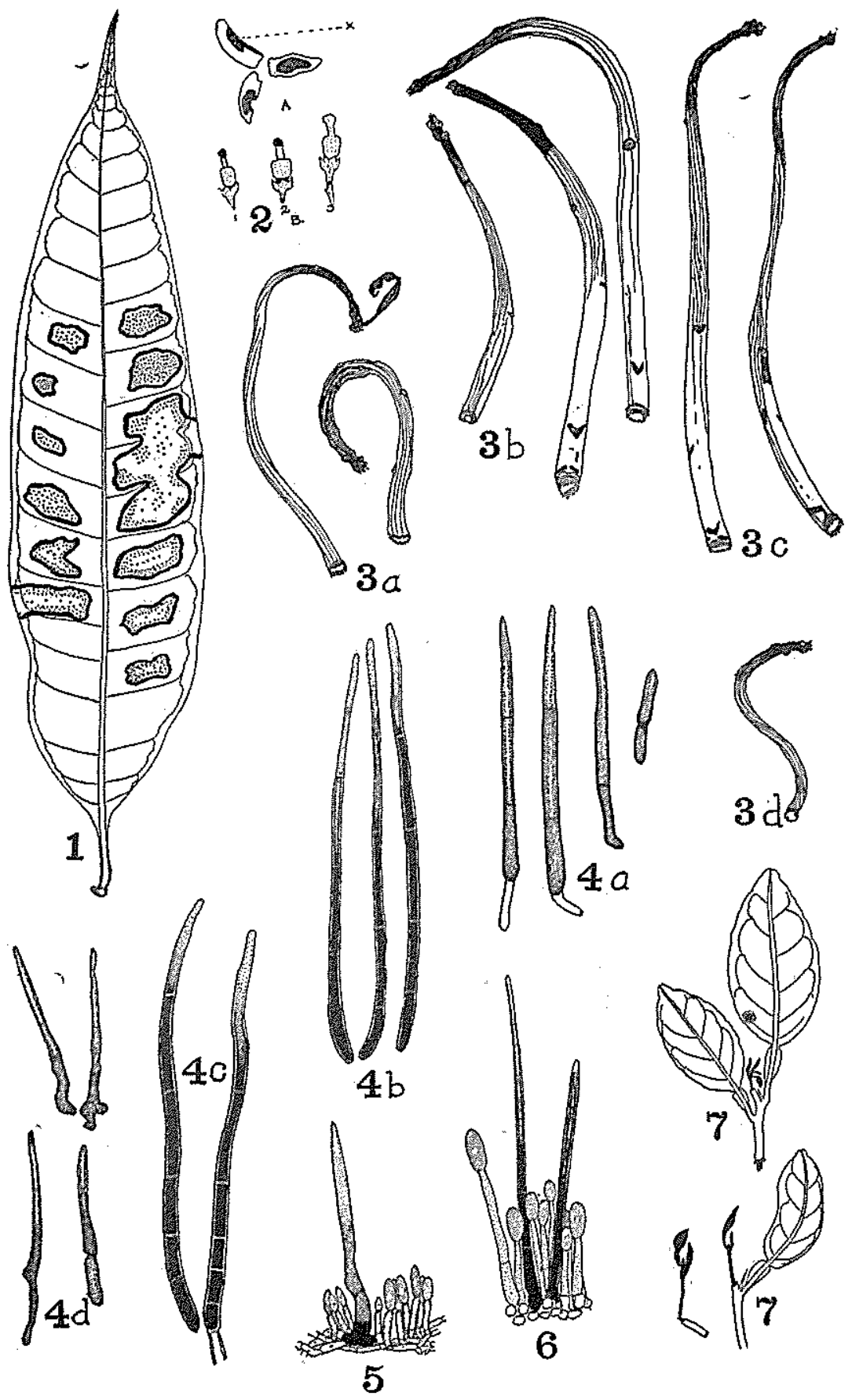

PLATE I 


\section{IEGEND FOR PLATE II}

Figves 8.-Spores of G. limeticolam showing blunt ends.

FIGURE 9.-Spores of $O$. glocosporioides showing blunt ends.

FIGURE 10.-Spores of 6 . limeticolum showing constriction.

FIGUn 11.-Spores of $O$. gloeosporioides showing constriction.

FIGURE 12.-Spores of $G$. limetlicolum showing ends more or less pointed.

Frgure 13.-Spores of $O$. gloeosporioides showing ends more or less pointed.

FIGUnE 14.-Shows charaeter of the plasma of spores of $G$. limeticolum. 


$$
\begin{aligned}
& \text { Drim: } 988 \text { - }
\end{aligned}
$$

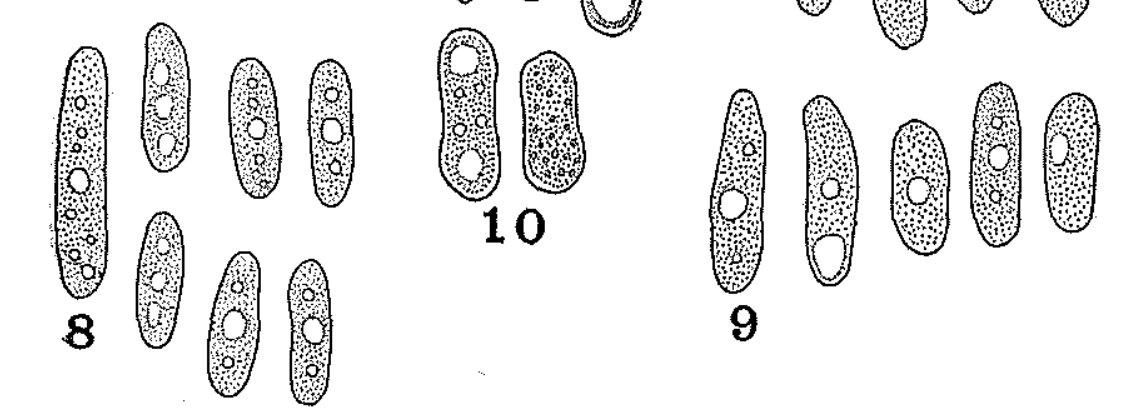

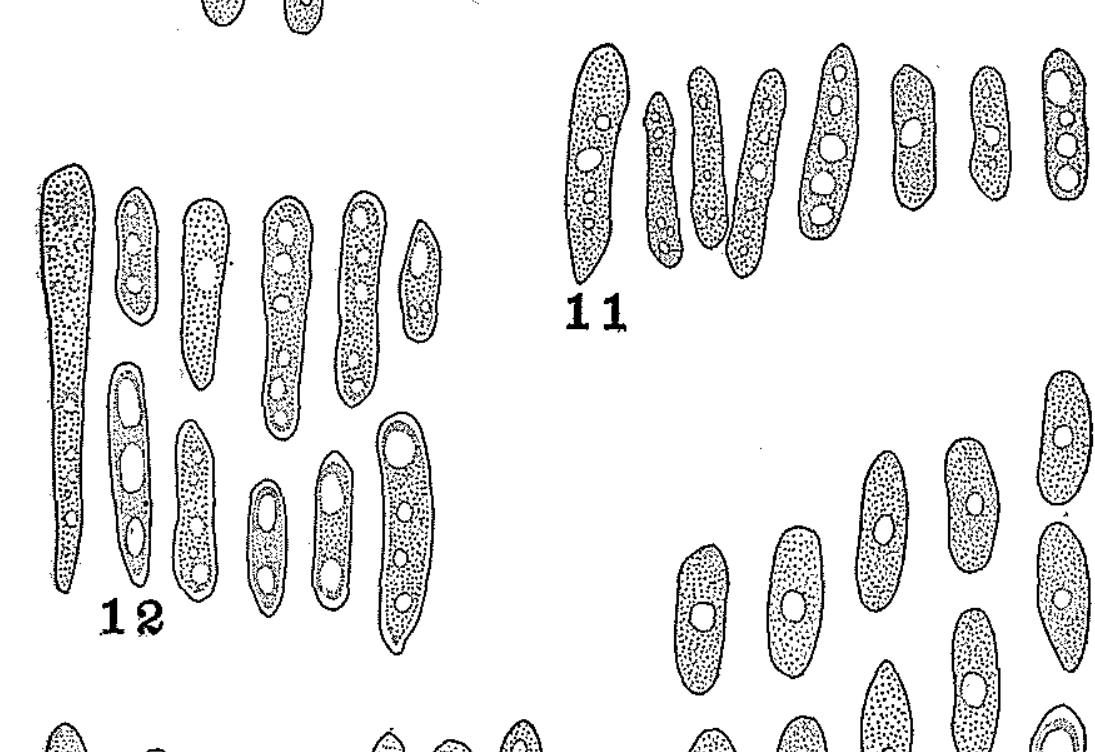

$$
\begin{aligned}
& \text { D H D }
\end{aligned}
$$




\section{LEGEND FOR PLATE III}

FraURe 15.--Shows character of the plasma of spores of 0 . glocosporioides. Fuvne 16.-Spores of $G$. limetticolum showing contraction of the plasma.

Figur: 17.-Spores of $G$. limetticolum showing different forms and shapes which ocear in culture media.

FIGURE 18.--Spores of 6 . glocosporioides showing various forms and shapes which oced in culture media.

FIGUne 19.-Conidiophores of the avocado culture of 0 . glocosporioides.

Figure 20.-Conidiophore of the mango culture of $C$. glocosporioides.

Figure 21.-Conidiophore of the lime fungus Glocesporitum limetticolum. 
THE ANTHRACNOSES OF CITRUS FRUTTS, MANGO AND AVOCADO

a

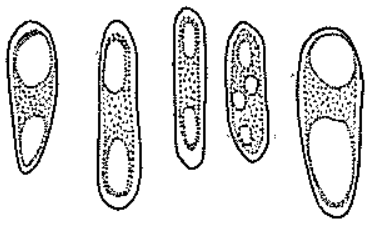

(4)

9016

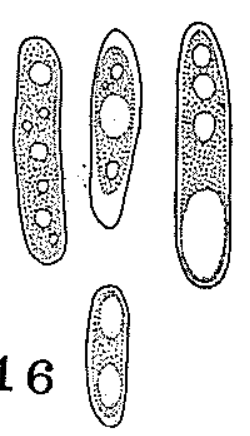

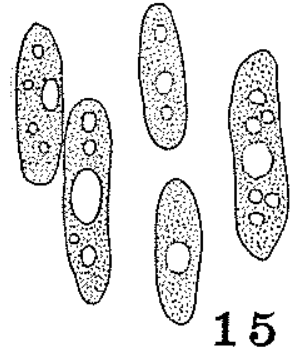

(2)
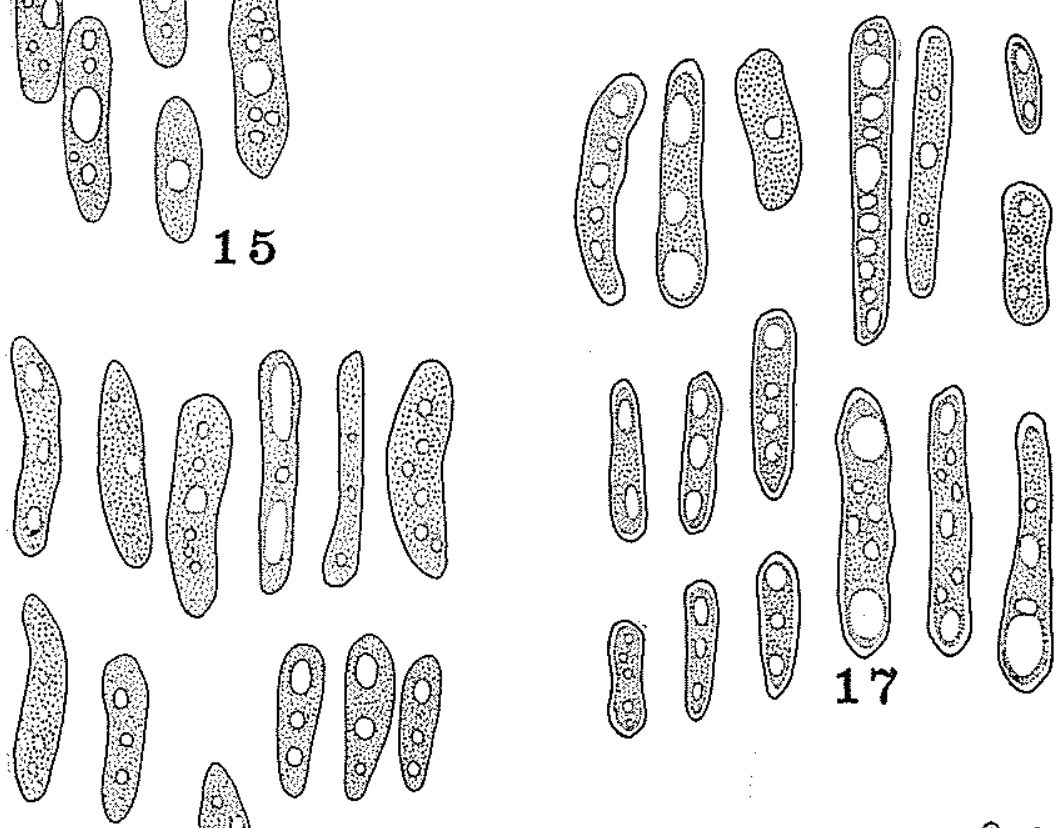

(1)
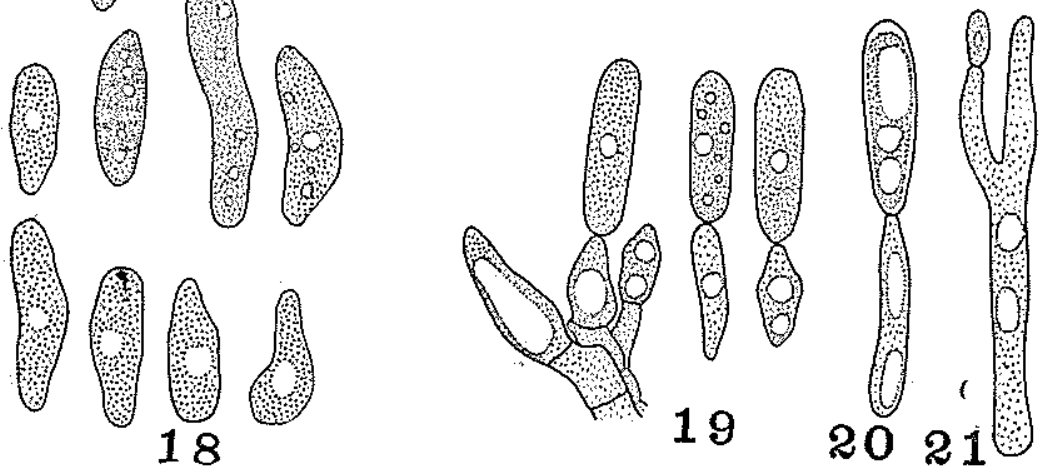


\section{IEGEND FOR PIATE IV}

Figure 22.-Colletotrichum glocosporioides on +15 nutrient agar. Culture from orsage. Figurs 23.-O. glocosporioides on -15 nutrient agar. Same culture as in Fig. 22.

Figure 24.-C. gloeosporioides on +15 agar. Culture from lime.

Frgune 25.-C. glocosporioides on -15 agar. Same culture as in Fig. 24.

Figure 20.-C. gloeosporioides on multose agar. Culture from orange.

Figune 27,-C, glocosporioides on maltoge agar. Culture from lime. 
THE ANTHRACNOSES OF CITRUS FRUITS, MANGO AND AVOCADO 59

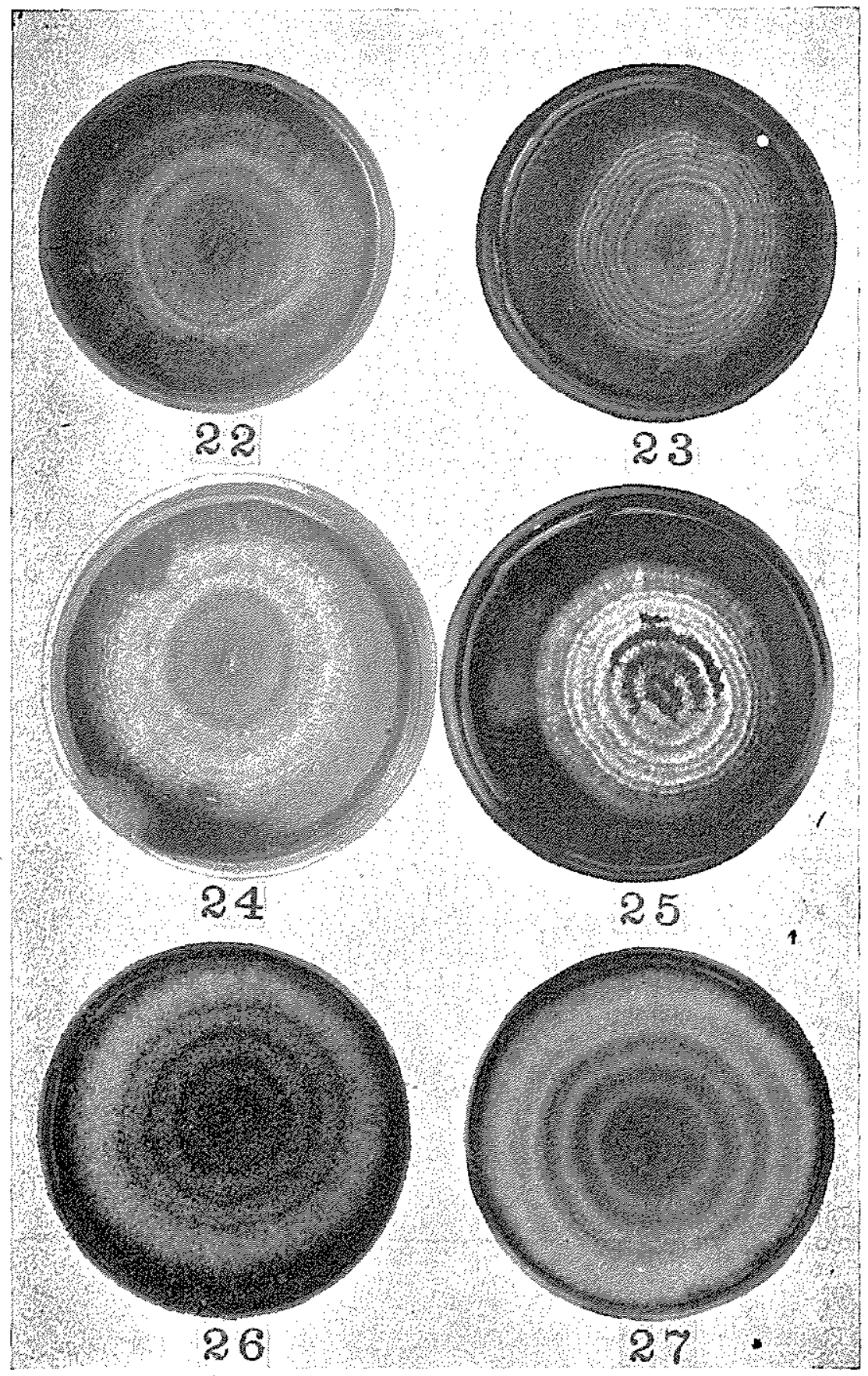




\section{LEGEND FOR PLATE V}

FIGVRE 38.-Glacosporium limetticolum on maltose agar.

Finve 29.-G. limeticolun on maltese agr. Diferent culture from Fig. 28.

Figure 30.-G. Iimetticnlum on lactose arar.

Fraure 31.-C. glocosporioides on lactote agrar. Culture from mango.

Figcre 32.-C, glocosporioidss on suerose agar. Culture from mango.

JisGre 33.-C. glocosporiotios on sucrose arar. Culture from avocado. 

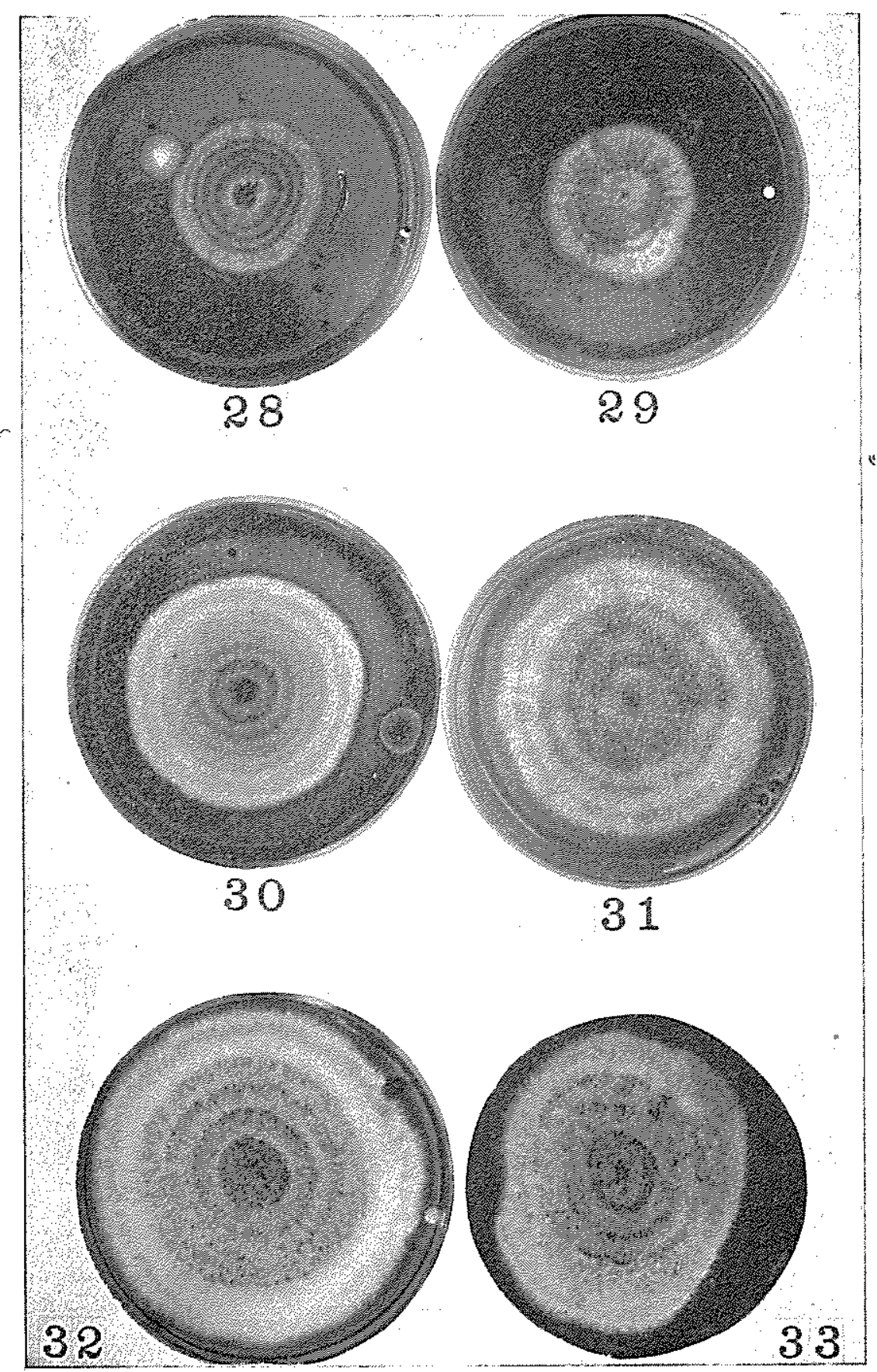

PLATE V 


\section{LEGEND FOR PLATE VI}

FIGURE 34.-O. gloeosporioides on oat-meal agar. Culture from avocado,

FIGURE 35.-C. gloeosporioides on glucose agar. Culture from avocado.

FIGURE 36.-C. gloeosporioides on corn-meal agar. Culture from avocado.

FIGURE 37.-Canker or fruit spot of the mango.

Figure 38.-Canker or fruit spot of the lime. 62 
THE ANTHRACNOSES OF CITRUS FRUITS, MANGO AND AVOCADO 63

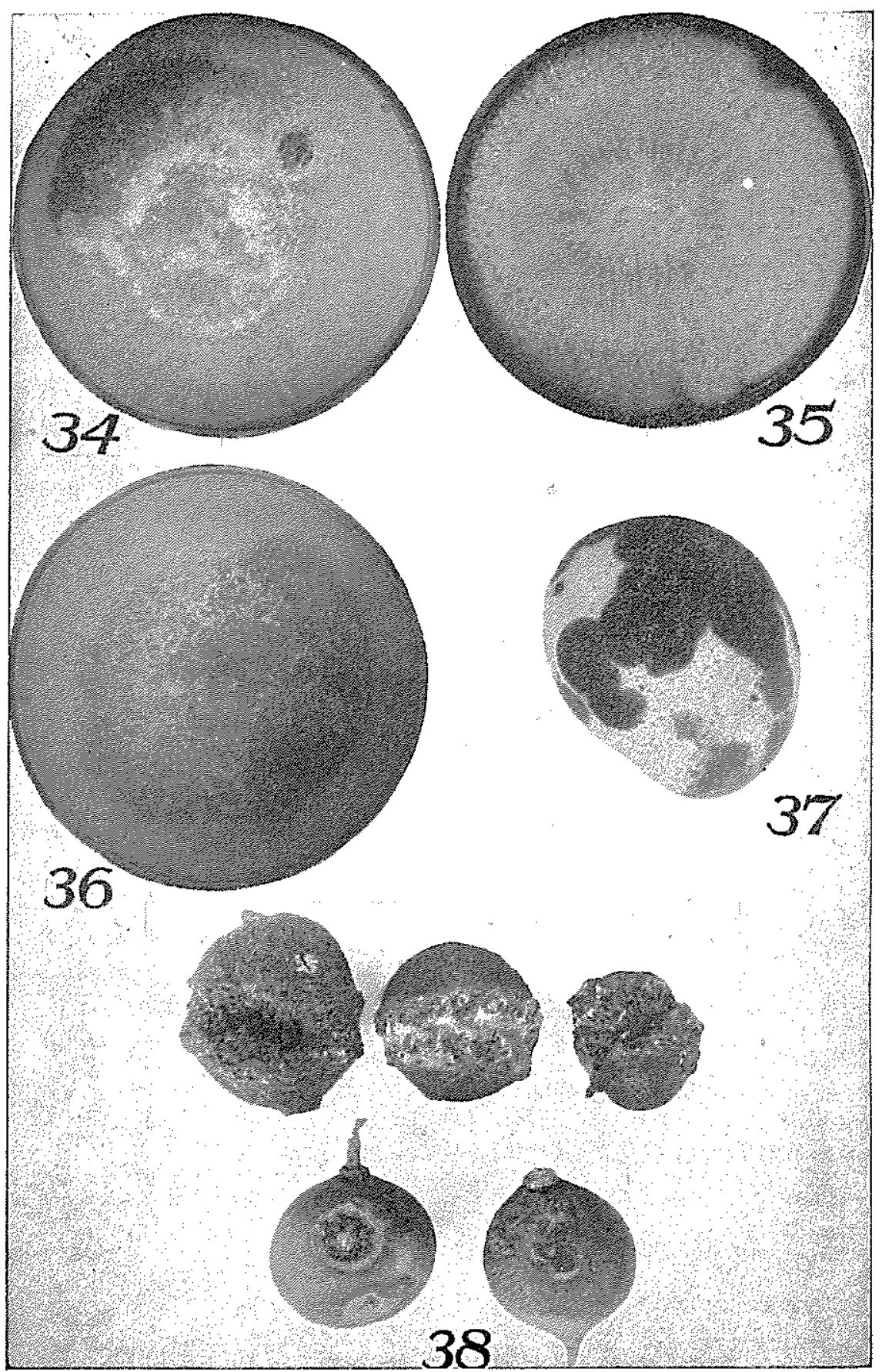

